\title{
SOCIAL HEALTH INSURANCE LITERACY: LESSON LEARNED FROM SOCIAL INSURANCE FOR MATERNITY CARE BY NATIONAL HEALTH INSURANCE PROGRAMME
}

\author{
Literasi Asuransi Kesehatan Sosial: Pelajaran yang Bisa Diambil dari Jaminan \\ Persalinan untuk Jaminan Kesehatan Nasional
}

\author{
*Choirun Nisa"1, Intan Nina Sari² \\ ${ }^{1}$ Faculty of Public Health, Universitas Airlangga, Indonesia \\ ${ }^{2}$ BPJS Kesehatan Pasuruan, Indonesia \\ *Correspondence: choirun.nisa-2016@fkm.unair.ac.id
}

\begin{abstract}
Background: Health insurance is a right for all Indonesian citizens. To provide this, the Indonesian government must provide health services that are equitable, fair, and affordable for all levels of society. Before National Health Insurance (JKN) was established, the government launched Social Insurance for Maternity Care or Jaminan Persalinan (Jampersal) as a special health facility for pre-pregnant to post-partum mothers. The JKN program will run well if it is accompanied with good health service literacy of the community.

Aims: This study aims to analyze the relationship of social health insurance literacy with the utilization of Jampersal and predict the response towards JKN utilization based on Jampersal mothers. These responses can be used as an input for JKN improvement.

Methods: This research is a descriptive study that focuses on the experience of the subjects. The study does so by analyzing Jampersal users' response and utilizing it for the improvement of JKN. The respondents of this study are Jampersal and non-Jampersal mothers consisting of 75 pregnant and post-partum mothers.

Results: The results show that the number of Jampersal users (47\%) were less than non Jampersal (53\%) with a ratio of 2:3. In addition, literacy about Jampersal of Jampersal mothers' was higher (28 out of 30 people - $93.33 \%$ ) compared to non Jampersal mothers (29 out of 45 people - $64.44 \%$ ).

Conclusions: This study concludes that there is a lack of promotion of government programs, especially social health insurance. What needs to be done to improve participation and use of social health insurance is to encourage primary healthcare centers to promote the programs. Intervention policy, especially by educating the communities, is necessary for the improvement of JKN literacy.
\end{abstract}

Keywords: Literacy, Participation, Social health insurance.

\section{ABSTRAK}

Latar Belakang: Jaminan Kesehatan adalah hak yang harus diperoleh seluruh Warga Negara Indonesia. Upaya mewujudkan hak tersebut pemerintah harus menyelenggarakan pelayanan kesehatan yang merata, adil dan terjangkau bagi seluruh lapisan masyarakat. Sebelum adanya JKN, pemerintah membuat Jampersal sebagai sarana kesehatan khusus ibu pra hamil hingga nifas. Program JKN akan berjalan dengan baik jika diringi dengan literasi masyarakat yang baik.

Tujuan: Penelitian ini dilakukan untuk menganalisis hubungan literasi asuransi kesehatan sosial dengan pemanfaatan Jampersal dan memprediksi perilaku pemanfaatan JKN berdasarkan literasi yang dimiliki oleh ibu pengguna Jampersal yang hasilnya bisa digunakan untuk kemajuan JKN.

Metode: Penelitian ini adalah penelitian deskriptif dengan melihat pengalaman serta menganalisis ibu yang dulunya bersalin menggunakan Jampersal pada saat masih menggunakan Jampersal yang selanjutnya bisa dimanfaatkan oleh JKN. Responden penelitian ini adalah sebagian ibu pengguna Jampersal dan Non-Jampersal yang terdiri dari ibu hamil dan ibu nifas sebanyak 75 responden.

Hasil: Hasil penelitian menunjukkan bahwa pengguna Jampersal lebih sedikit (47\%) daripada Non Jampersal (53\%) dengan perbandingan 2:3. Selain itu, literasi ibu pengguna Jampersal tentang Jampersal lebih banyak (28 orang) dari 30 orang (93,33\%) dibandingkan dengan kelompok ibu Non Jampersal (29 orang) dari 45 orang $(64,44 \%)$.

Kesimpulan: Kesimpulannya adalah kurangnya promosi program pemerintah khususnya asuransi kesehatan sosial oleh fasilitas pelayanan kesehatan. Hal yang perlu dilakukan untuk meningkatkan partisipasi dan penggunaan asuransi kesehatan sosial adalah mendorong Puskesmas untuk mempromosikan program dan perlu ada intervensi khusus untuk meningkatkan literasi JKN dengan mendidik masyarakat.

Kata Kunci: Asuransi kesehatan sosial, Kepesertaan, Literasi. 


\section{INTRODUCTION}

In Indonesia, citizens have basic rights to their health in accordance with Pancasila, the philosophy and principle of the country. The right to live healthy is also stated in the 1945 Constitution article $28 \mathrm{H}$ and article 34 and regulated in Law 36/2009. Law $36 / 2009$ affirms that everyone has equal rights to affordable and quality health services. Consequently, every citizen also has the obligation to participate in social health insurance programs. The National Health Insurance Program or Jaminan Kesehatan Nasional (JKN) handbook on the socialization of National Social Security System 2014 or Sistem Jaminan Sosial Nasional (SJSN) states that the government is responsible for implementing public health insurance through JKN. The government has established several forms of social health insurance through PT Askes (Persero) and PT Jamsostek (Persero) which serve civil servants, pensioners, veterans, and private employees. For poor communities, the government has the so called free health care scheme (Jamkesmas), social insurance for maternity care (Jampersal), and local government's free health care scheme (Jamkesda). However, since the management is mandated to local governments, the monitoring and controlling of the programs is difficult to be done (Putri, 2014).

In 2004, Law No.40 concerning National Social Security System was passed to overcome this problem. The Law 40/2004 mandates that social security, including $\mathrm{JKN}$, is mandatory for all residents and managed by the Social Security Agency or Badan Penyelenggara Jaminan Sosial (BPJS). JKN program will run well if it is accompanied by good literacy of the receiving communities, as stated in the book Understanding National Health Insurance (JKN) (Putri, 2014). The communities are expected to be aware of the health insurance schemes, promoted through the health insurance literacy programme.

Social health insurance literacy is the measure of one's knowledge and confidence to find, evaluate, and choose the most suitable health plans by considering their financial and health conditions (or their family), and maintain the plan after the registration (Consumer Union, 2012). Individuals with low social health insurance literacy face more challenges in accessing social health insurance services and consequently low social health insurance (Ramadhan, 2017).

Pregnant and post-partum mothers, more than other groups, are among those with lower social health insurance literacy, as occurred in the Primary Healthcare Center of Dupak, Surabaya. For example, a substantial number of mothers receiving health care in the Public Health Centre of Dupak lack sufficient knowledge of Jampersal. Even the few Jampersal users do not know the objectives, requirements, benefits, and services of Jampersal. The pregnant and post-partum mothers who actually know about Jampersal often prefer to check their condition at other health service facilities, such as hospitals (Sari and Pudjiraharjo, 2013).

Adi (2015) stated that socio-economic factors and social health literacy need to be considered to increase participation in the JKN program. Providing education to communities is highly recommended to improve social health insurance literacy and participation in the JKN program. Sihombing (2014) stated that there was a relationship between education and JKN participation. Higher education is linked with greater awareness and participation in the JKN program (Rumengan, Umboh and Kandou, 2015).

This study was conducted to investigate the relationship between social health insurance literacy and the utilization of Jampersal. The objective of this study is to find out the response of using National Health Insurance (JKN) based on Jampersal users' literacy in which the results can be used for JKN improvement.

\section{METHOD}

The population of this study are all Jampersal and non-Jampersal mothers consisting of pregnant and post-partum mothers receiving health care in the Primary Healthcare Center of Dupak, Surabaya, Indonesia. Jampersal and non-Jampersal mothers consisting of pregnant mothers were sampled using one-stage cluster sampling method. Sampling was determined based on the proportion of pregnant women and post-partum mothers in the community units. Community unit 1 consisted of 2 respondents, community unit 2 consisted of 10 respondents, community unit 3 has 8 respondents, community unit 4 has 16 respondents, and community unit 5 consisted of 39 respondents.

Data were collected by conducting structured interviews with a questionnaire as guide. Before the questionnaires were distributed, the researcher obtained voluntary informed consent after explaining research objectives to the respondents-The collected data were processed (manually sorted) and analyzed using basic descriptive statistics.

\section{RESULTS AND DISCUSSION}

Jampersal was not fully utilized by pregnant and post-partum mothers to do proper health checkup at health facilities. Some factors that influenced the lack of Jampersal literacy about participation in social health insurance and utilization of health services were insurance status and income status. Non-Jampersal users were more $(60 \%)$ than Jampersal users (40\%). However, the number of non-Jampersal users who earned more than the Regional Minimum Wage is larger $(71 \%)$ than Jampersal users (43\%) earning the same. These data were obtained from Primary Healthcare Center of Dupak in 2012. 
Table 1. Jampersal and Non-Jampersal Pregnant Mothers Characteristics in the Primary Healthcare Center of Dupak in 2012.

\begin{tabular}{|c|c|c|c|c|c|c|}
\hline \multirow{3}{*}{ Characteristics } & \multicolumn{4}{|c|}{ Mother } & \multirow{3}{*}{$\mathbf{N}$} & \multirow{3}{*}{$\%$} \\
\hline & \multicolumn{2}{|c|}{ Pregnant } & \multicolumn{2}{|c|}{ Postpartum } & & \\
\hline & $\mathbf{n}$ & $\%$ & $\mathbf{n}$ & $\%$ & & \\
\hline \multicolumn{7}{|l|}{ Insurance Status } \\
\hline Jampersal & 15 & 50 & 15 & 50 & 30 & 40 \\
\hline Non-Jampersal & 29 & 64 & 16 & 36 & 45 & 60 \\
\hline \multicolumn{7}{|l|}{ Jampersal User's Income } \\
\hline$<$ Regional Minimum Wage & 8 & 27 & 9 & 30 & 17 & 57 \\
\hline > Regional Minimum Wage & 7 & 23 & 6 & 20 & 13 & 43 \\
\hline \multicolumn{7}{|l|}{ Non-Jampersal Users' Income } \\
\hline$<$ Regional Minimum Wage & 9 & 20 & 4 & 9 & 13 & 29 \\
\hline$>$ Regional Minimum Wage & 20 & 44 & 12 & 27 & 32 & 71 \\
\hline
\end{tabular}

High community literacy strongly supports the success of the Jampersal program which consequently leads to higher utilization of health services. Figure 1 illustrates pregnant and postpartum mothers' literacy on social health insurance in the Primary Healthcare Center of Dupak in 2012.

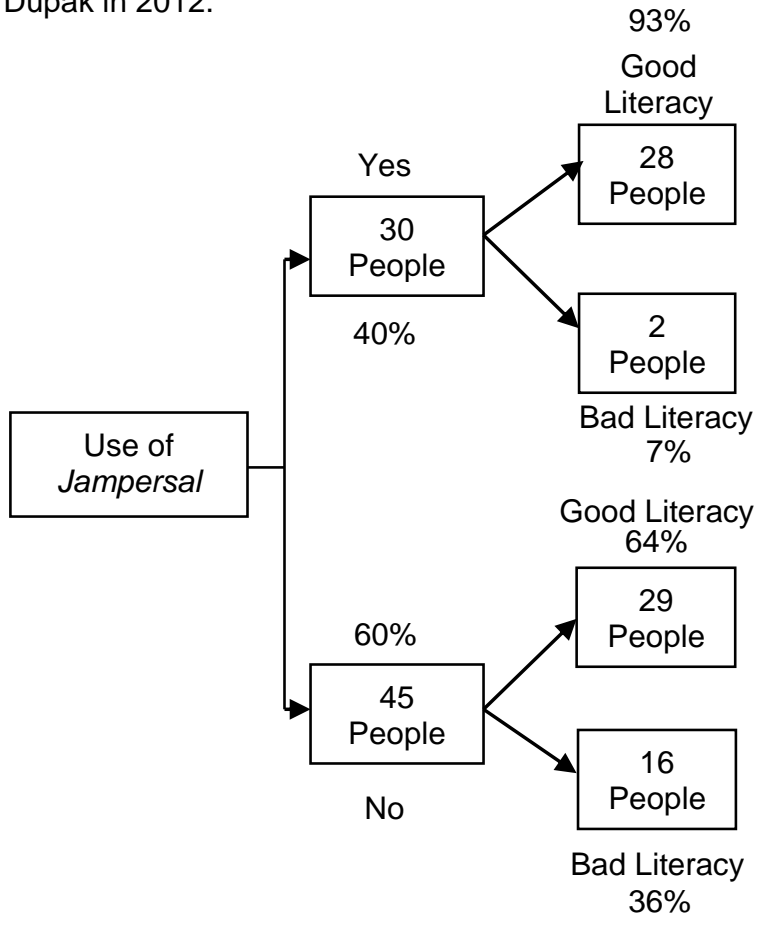

Figure 1. Pregnant and Postpartum Mothers Literacy for Social Health Insurance in the Primary Healthcare Center of Dupak, Surabaya in 2012.

Essentially, Jampersal users' literacy about Jampersal was better (93\%) than non-Jampersal $(64 \%)$ in the study population. The findings show that the lack of literacy on social health insurance could affect participation in social health insurance and the utilization of health services. From the table and figure above, it can be concluded that there are several reasons that cause respondents to be reluctant to use Jampersal, such as insurance status, income, and literacy.

The first factor that influences the use of health insurance is insurance status. The results show that $60 \%$ of respondents were non-social health insurance users. According to Sari and Pudjirahajo (2013), the studied population did not use social health insurance because they did not know the government program well. Similarly, this finding shows that a larger portion of the population were not JKN participants. Lawrence Green's behavioural theory states that knowledge is one of the predisposing factors that influences a person's tendency towards something which will result in behaviour. Results from Purwaningsih's research (2016) show that $84.3 \%$ of her respondents with good knowledge became JKN members. Thus, it can be concluded that there is a relationship between knowledge and the role of family heads in using JKN (Purwaningsih, 2016).

The second factor that greatly influences the use of social health insurance is income. Based on Table $1,71 \%$ of respondents who did not use social health insurance earned more than the regional minimum wage. It was because literacy on social health insurance was low. Low literacy on health insurance likely lowers the interest to use social health insurance. In addition, those who had high income might prefer to pay on their own rather than to use social health insurance, with the objective to obtain better services. Abi (2015) states that socioeconomic status and health literacy need to be considered in the effort to increase the participation in the National Health Insurance program. One of the solution to improve health insurance literacy is to create wider-reaching publication and educate the public about JKN (Adi, 2015). This is inversely proportional to Purwaningsih who found that people with good knowledge on JKN and sufficient income are more likely to participate in JKN. Whereas, people with less knowledge and less income show hesitancy to participate in JKN because they prefer to spend their income on daily needs rather than the JKN (Purwaningsih, 2016). 
The reason for respondents to not using social health insurance is literacy. According to Santosa (Santosa, 2012), access to health information is the most dominant factor associated with the level of health literacy. Based on his description (2012), there is a relationship between public literacy on social health insurance and participation in JKN which results in less utilization of health services. Utilization of health services refers to the act of seeking health service done by individual or a group. According to Notoatmodjo (2014), treatment-seeking behavior is the individual's and group's action to seek or utilize treatment. The Four As Goods theory (1987) in Hausmann-muela, Ribera and Nyamongo (2003) stated that utilizing the different categories of healthseeking behavior can be traced to availability, accessibility, affordability, and acceptability of health services. Reviewing Jampersal program based on the community's experience before JKN existed will make it easier for readers to find out what they can benefit from JKN program.

According to Rahangiar, Balqis and Nurhayani (2013), mothers do not use Jampersal surgery because they do not frequently carry out antenatal care in the Primary Healthcare Center due to the lack of satisfaction from the services. Moreover, some mothers who have more than one pregnancy experience different professional and traditional health treatment. It is also one of the factors that affect the lack of Jampersal utilization. In addition, they are also afraid of getting bad service at health service facilities if they use social health insurance. This is evidenced by the differences in health services received by people using social health insurance and those using general health insurance. If the quality of service at health facilities (Primary Healthcare Centers or hospitals) is good, the community will feel satisfied (Syah R, 2017).

According to Aryani and Rosita (2010), service quality has an influence on customer satisfaction in the Faculty of Social Science and Political Science University of Indonesia. Their study shows that the higher the quality of service is, the higher the customer satisfaction will be (Adriana et al., 2014). If the customers are satisfied, customer loyalty for the company will increase. Customers' satisfaction or dissatisfaction with a service will have a tremendous impact on the behaviour of future use. Companies that succeed in satisfying their customers will benefit from high customer loyalty. Therefore, the key to keep the company active and existent in this competitive era is the company's ability to preserve customers.

The availability factor in health services greatly supports the utilization of Jampersal program in Primary Healthcare Centers. In this case, health service facilities' availability is reflected by the availability of medicines for pregnant and postpartum mothers. The availability of health facilities is one factor that encourages people to utilize Jampersal.

The distance from the house to the health service facility can affect the frequency of visits. The closer the distance is, the more frequent the visits are,and vice versa. Research by Adriana et al. (2014) shows that the availability of health facilities for maternity which are equipped with trained or expert personnel, adequate equipment, and medicine technology is the main prerequisite. However, it does not guarantee the utilization of health services by mothers because of costly and limited transportation and poor road condition. Basically, maternal and infant mortality commonly occur due to complications and failure to get adequate medical services as a result of difficult access. The results of the follow-up analysis of basic health research in 2007 indicate that there is a significant relationship between distance and time spent to go to village maternity clinic or polindes (Paramita and Setia Pranata, 2013).

Latest analysis shows that costs tend to inhibit rather than improve services for poor people. Maternity insurance is very helpful for the poor because the costs of labor and antenatal care have been entirely liquidated by the government through the insurance (Rahangiar, Balqis and Nurhayani, 2013). To improve health facilities utilization by poor communities, there is a need for support from nurses, doctors, and midwives. The support can be from the health worker's response when serving patients with friendly communication, guiding them to see a doctor, and informing them about the Jampersal program. It can be interpreted that there is a significant relationship between health worker's support and the use of Jampersal cards, as demonstrated in a previous study (Purba, 2011.

Based on the description above, many shortcomings occurred in the implementation of Jampersal program due to some community's perceptions and characteristics that greatly influence the selection of good health services. Fitriani, Rusnoto and Aisyah (2014) states that the lack of knowledge about Jampersal is a result of ignorance and lack of interest in accessing information about Jampersal. In addition, health workers do not really promote Jampersal so that community's literacy on Jampersal is low. Even though mothers have insufficient knowledge about Jampersal, they still use Jampersal because they are interested in the free service. Jampersal itself is directed for pregnant and post-partum mothers with low income. Uncertainties on health services with Jampersal procedures also become a public debate regarding the feasibility of the health services. The negative attitude shown is due to a lack of understanding about Jampersal and previous experience by mothers and other people around them. Part from knowledge, attitudes, and lack of information, another reason not to use Jampersal is that mothers already have had other labor 
insurances such as delivery insurance program from their office.

After reviewing Jampersal, National Health Insurance (JKN) program is expected to develop its system better and more user friendly. According to Purwaningsih (2016), there is a relationship between knowledge and the role of family heads in JKN $(p=0.000)$. It is supported by Rohmawati's research (2014), which shows that there is a relationship between education and selection of independent JKN contribution types $(p=0.000)$. Higher level of education will clearly affect an individual's capacity to think, make better decisions in selecting health plans, and make plannings for his family. One of which is shown by participating in JKN program (Berungan and Budhi, 2004). Purwaningsih (2016) states that people with higher literacy and sufficient income are more likely participate in JKN than those with less or no knowledge and lower income. The latter group prefer to spend their money on other, more apparent needs. Research shows that there is a significant relationship between income and role of family head in national health insurance utilization $(p$ $=0.027$ ) (Purwaningsih, 2016). This research is in line with Rohmawati's (2014), which shows that there is a relationship between income and fee type selection $(p=0.000)$. Kurniawan and Intiasari (2012) show that there is a relationship between work and ownership of voluntary health insurance $(p$ $=0.001$ )

Purwaningsih (2016) states that community's positive attitude requires sufficient knowledge and information, so people can make the right decision. The results show that there is a significant relationship between the attitude and participation of family head in national health insurance ( $p$ value $=$ 0.002 ). A positive attitude towards independent JKN participants can be supported by the majority of 3040 year-old respondents (Purwaningsih, 2016). Someone in this age range has better awareness concerning their health needs (Kotler and Armstrong, 2010). This argument is supported by Kurniawan and Intiasari (2012) who show that age correlates with owning health insurance $(p=0.001)$. Information about health services is one of supporting factors for health service condition, which makes it mandatory to be available to individuals, so more information is clearly provided through BPJS to improve JKN utilization (Notoatmodjo, 2014). The results of Purwaningsih's study show that there is a significant relationship between information obtained by family heads and participation in national health insurance $(p=0.026)$ (Purwaningsih, 2016).

Purwaningsih's research (2016) states that someone with high education has better opinion from taking into account the available information to make decision on whether to participate JKN or not. This is in line with Widhiastuti's research (2015), which found that $85.19 \%$ of non JKN participants who obtained information about JKN were interested to be independent JKN participants, and only $14.81 \%$ who did not receive information did not engage in JKN program due to financial reasons.

Social Health Insurance...

The role of family members has an influence to the family's decision making. In the case group of a family with $<4$ members, the family can support itself better, because having a steady income and an ideal number of family members lowers the cost associated with JKN. However, if the number of family members is $>4$, the JKN is less likely to be affordable by the family members due to the associated costs. The results of Purwaningsih's research (2016) show that there is a significant relationship between family support and role of family heads' participation in National Health Insurance or Jaminan Kesehatan Nasional (JKN) ( $p$ $=0.000$ ) (Purwaningsih, 2016).

Trust in JKN health services is closely related to the participation in the JKN program. For example, if positive expectations for JKN health services are met, such can affect the respondent's participation status in JKN program. The results of Purwaningsih's research (2016) show that more respondents believe in JKN health. Most of them said that JKN is a good program, and it can help the community to meet their health needs. However, some shortcomings still make people have low trust in JKN health services. According to Nadiyah, Lusiana and Subirman (2017), bad experiences in utilizing health services make their respondents think that JKN health facilities are not able to serve them well and do not meet respondents' expectations. About $49 \%$ of the respondents mentioned that there are different treatment between patients with health insurance and without health insurance. It lowers the community's trust in JKN health services. There were $35 \%$ of respondents who said drugs given to them were the generic ones. Based on the Phi correlation coefficient test results, which is 0.226 more than 0.05 , there is no correlation between trust to $\mathrm{JKN}$ health services and participation in JKN program due to unmet expectations (Nadiyah, Lusiana and Subirman, 2017).

The responses on Jampersal use above can be helpful for the advancement of JKN and evaluation on issues related to the participation and utilization of social health insurance. Based on the respondents' reasons for not using JKN, one's literacy on social health insurance does not guarantee participation in JKN. Individuals with good social health insurance literacy do not have more consideration to become a JKN participant and vice versa. Low literacy on JKN makes the participants uninterested in using JKN. In relation to literacy, community participation in health insurance is also often associated with the utilization of health services. The quality of health services is also a major factor in determining which health facilities are good and satisfying. If the health service received using health insurance is not satisfactory , the community will turn to other health insurances and pay higher medical expenses suitable to their needs. Lessons from Jampersal evaluation can be used as a reference to develop better and more well 
distributed JKN system so that all Indonesians can access proper health services.

Therefore, motivation from other parties to use social health insurance can increase community participation in the JKN program. In addition, any health insurance will have a positive impact on the community's economic and social condition. This is because health insurance provides a sense of security to the users and avoids financial problem due to unexpected health costs. The study is only based on previous research that also discusses Jampersal utilization by pregnant and postpartum women in the Primary Healthcare Center of Dupak in 2012, so it does not provide current actual use of social health insurance. Therefore, further research is needed to describe the use of social health insurance.

\section{CONCLUSION}

The study shows that high literacy on social health insurance may influence community participation if accompanied by program promotion through media. Lack of program promotion may cause many people fail to understand the benefits of using JKN, though participating in JKN can improve the quality of life of the participants. The lack of community literacy on the participation and utilization of social health insurance also hampers participation in the program.

What needs to be done to improve participation and utilization of social health insurance, therefore, is to encourage Primary Healthcare Centers to promote the program. Furthermore, the community should be more active in seeking knowledge about government's health programs such as the JKN. In summary, it is necessary to have specific interventions to improve JKN literacy by educating the community.

\section{CONFLICT OF INTEREST}

The authors declare that they have no conflict of interests.

\section{REFERENCES}

Abi, A. (2015) Tingkat Literasi Kesehatan dan Kepesertaan dalam Program Jaminan kesehatan Nasional (JKN) di Kabupaten Sleman Daerah Istimewa Yogyakarta. Thesis. Universitas Gajah Mada.

Adriana, N. et al. (2014) 'Akses Pelayanan Kesehatan Berhubungan dengan Pemanfaatan Fasilitas Persalinan yang Memadai di Puskesmas Kawangu Access to Health Service related to Use of Antenatal Care Facilities at the Kawangu Health Centre - East Sumba Pendahuluan Menurunkan kematian', Public Health and Preventive Medicine Archive, 2, pp. 175-180. Available at:

https://ojs.unud.ac.id/index.php/phpma/article /view/13237/8917.

Aryani, D. and Rosinta, F. (2010) 'Pengaruh
Kualitas Layanan terhadap Kepuasan Pelanggan dalam Membentuk Loyalitas Pelanggan', Jurnal IImu Administrasi dan Organisasi, 17(2), pp. 114-126. doi: 10.20476/jbb.v17i2.632.

Berungan, W. and Budhi, J. (2004) Psikologi Sosial. 3rd edn. Bandung: Refika Aditama.

Consumer Union (2012) Measuring Health Insurance LiteRoundtable, Expertracy: A Call to Action $A$ Report from the Health Insurance Literacy Expert Roundtable. United States.

Fitriani, A., Rusnoto and Aisyah, N. (2013) 'Hubungan Tingkat Pengetahuan dan Sikap dengan Keikutsertaan Jaminan Persalinan pada Ibu Hamil di Puskesmas Kedung II Kecamatan Kedung Kabupaten Jepara', Jurnal IImu Keperawatan dan kebidanan, 5(3).

Hausmann-muela, S., Ribera, J. M. and Nyamongo, I. (2003) Health-seeking behaviour and the health system response. 14. London.

Kotler, P. and Armstrong, G. (2012) Principles of Marketing. 14th edn. Boston: Pearson Eduction.

Kurniawan, A. and Intiasari, A. D. 2012. 'Kebutuhan Jaminan Kesehatan Masyarakat di Wilayah Perdesaan Health Insurance Need in Rural Areas', Jurnal Kesehatan Masyarakat Nasional, 7(1), pp. 1-7.

Nadiyah, H., Lusiana, D. and Subirman (2017) 'Faktor-Faktor Yang Berhubungan Dengan Kepesertaan Program JKN di Wilayah Kerja Puskesmas Remaja Kota Samarinda', Jurnal Kebijakan Kesehatan Indonesia. Universitas Mulawarman. Samarinda, 6(2), pp. 66-72.

Notoatmodjo, S. (2014) IImu Perilaku Kesehatan. 2nd edn. Jakarta: PT. Rineka Cipta.

Paramita, A. and Setia Pranata, D. (2013) 'Analisis Faktor Pemanfaatan Polindes Menurut Konsep Model Perilaku Kesehatan ; ANDERSON ;(Analisis Lanjut Data RISKESDAS 2007)', Buletin Penelitian Kesehatan, 41(3), pp. 179-194.

Purba, T. R. N. (2012) Faktor-Faktor yang Berhubungan dengan Pemanfaatan Jamkesmas di Wilayah Puskesmas Kota Jambi Tahun 2011. Undergraduate Thesis. Universitas Indonesia.

Purwaningsih, S. B. (2016) Faktor-Faktor yang Berhubung dengan Keikutsertaan Masyarakat dalam Jaminan Kesehatan Nasional di Desa Tegalsari Kabupaten Ponorogo 2015. Master Thesis. Universitas Muhammadiyah Surakarta.

Putri, A. E. (2014) Paham JKN- Jaminan Kesehatan Nasional. 4th edn. Jakarta: Friedrich-EbertStiftung Kantor Perwakilan Indonesia bekerja sama dengan Dewan Jaminan Sosial Nasional (DJSN).

Rahangiar, F., Balqis and Nurhayani (2014) 'Faktor yang Berhubungan dengan Pemanfaatan Program Jaminan Persalinan di Puskesmas Ohoijang Kabupaten Maluku Tenggara'. Makassar: Universitas Hasanudin. Available at: http://repository.unhas.ac.id/handle/1234567 
$89 / 8765$

Ramadhan, S. R (2017) 'Tingkat Literasi Kesehatan pada Keluarga Penderita Penyakit Diabetes Mellitus di RSUD Dr. M. Soewandhie Surabaya', pp. 1-21. Universitas Airlangga.

Rohmawati, D. (2014) Hubungan Pegetahuan Sikap dan Sosial Ekonomi dengan Pemilihan Jenis luran Keikutsertaan JKN Mandiri pada Wilayah Cakupan JKN Tertinggi di Surakarta. Undergraduate Thesis. Universitas Muhammadiyah Surakarta.

Rumengan, D. S. S., Umboh, J. M. L. and Kandou, G. D. (2015) 'Faktor-Faktor yang Berhubungan dengan Pemanfaatan Pelayanan Kesehatan Pada Peserta BPJS Kesehatan di Puskesmas Paniki Bawah Kecamatan Mapanget Kota Manado', Jikmu, 05(2), pp. 88-100.

Santosa, K. S. (2012) Faktor-Faktor yang Berhubungan dengan Tingkat Kemelekan Kesehatan Pasien di Klinik Dokter Keluarga Fakultas Kedokteran Universitas Indonesia Kiara, DKI Jakarta Tahun. Master Thesis. University of Indonesia.

Sari, I. N. and Pudjiraharjo, W. J. (2013) 'Ekuitas Dalam Pemberian Pelayanan Kesehatan', Jurnal Administrasi Kesehatan Indonesia, 1(1), pp. 21-28. Available at: http://journal.unair.ac.id/downloadfull/JAKI48 20-1545aa673efullabstract.pdf.

Sihombing, N. I. (2014) Hubungan Karakteristik dan Persepsi Masyarakat tentang Jaminan Kesehatan Nasional (JKN) terhadap Keikutsertaan menjadi Peserta JKN di Kota Medan Tahun 2014. Undergraduate Thesis. Universitas Sumatera Utara Medan.

Syah R, M. A. T. (2017) Hubungan Persepsi Masyarakat Tentang Jaminan Kesehatan Nasional (JKN) Terhadap Keikutsertaan Menjadi Peserta BPJS Kesehatan di Wilayah Kerja Puskesmas Minasa Upa Kota Makassar 2017. Undergraduate Thesis. Universitas Hasanuddin Makassar.

Widhiastuti, I. A. P. (2015) Hubungan Faktor Sosiodemografi, Persepsi dan Sosialisasi dengan Kepesertaan pasien Rawat jalan dalam Program Jaminan Kesehatan Nasional secara Mandiri di Puskesmas I Despansar Timur. Master Thesis. Universitas Udayana. 